\title{
Subcutaneous continuous insulin infusion and control of blood glucose concentration in diabetics in third trimester of pregnancy
}

\author{
JONATHAN M POTTER, JOHN P D RECKLESS, DEREK R CULLEN
}

\section{Summary and conclusions}

The effect of subcutaneous continuous insulin infusion on the control of blood glucose concentrations was assessed in eight pregnant diabetics in the third trimester. Twenty-four-hour glucose profiles were obtained after strict inpatient control on conventional insulin regimens and after the start of the continuous infusion, which was maintained for 5-55 days. Mean 24-hour glucose concentrations $(6.2 \mathrm{mmol} / 1$ on conventional regimen, $5.9 \mathrm{mmol} / 1$ on continuous infusion; 111.6 and $106.2 \mathrm{mg} / 100 \mathrm{ml}$ respectively) and mean fasting concentrations (5.3 $v 6.2 \mathrm{mmol} / \mathrm{l} ; 95.4 v 111.6 \mathrm{mg} / 100 \mathrm{ml})$ were not significantly changed by continuous infusion. Diurnal variations in glucose concentration tended to be smaller on continuous infusion: standard deviation from mean 24-hour glucose concentration was reduced from 2.5 to $2.0 \mathrm{mmol} / 1$ (from 45 to $36 \mathrm{mg} / 100 \mathrm{ml}$ ), maximum excursion from 8.4 to $7.4 \mathrm{mmol} / 1$ (151.2 to $133.2 \mathrm{mg} / 100 \mathrm{ml}$ ), and $M$ value from 16 to 14 .

Subcutaneous continuous insulin infusion may be useful in limiting diurnal variations of blood glucose concentrations and warrants further investigation since such an action may be beneficial in the management of pregnant diabetics, in whom the best possible control of blood glucose concentrations is sought for the good of the fetus.

\section{Introduction}

Recently there has been a sharp reduction in the perinatal mortality rate associated with diabetes in pregnancy, ${ }^{12}$ and

Hallamshire Hospital, Sheffield S10 9JF

JONATHAN M POTTER, BM, MRCP, Novo research fellow in diabetes

JOHN P D RECKLESS, MD, MRCP, senior registrar in general medicine and diabetes mellitus (now consultant physician, Royal United Hospital, Bath BA1 3NG)

DEREK R CULLEN, MD, FRCP, consultant physician much evidence suggests that improved control of maternal blood glucose concentrations has been an important contributory factor. $^{34}$ Pedersen suggested that closer supervision of the pregnancy, and particularly of the mother's diabetes, with prolonged inpatient management improved perinatal survival, and others have confirmed these findings. ${ }^{\circ}$ Karlsson and Kjellmer have presented evidence that mean daily blood glucose concentrations under $5.7 \mathrm{mmol} / \mathrm{l}(102.6 \mathrm{mg} / 100 \mathrm{ml})$ during the last trimester in pregnant diabetics are associated with a significant reduction in fetal mortality. "There is still, however, an increased mortality and morbidity associated with diabetes in pregnancy with total perinatal mortality rates of $5 \%$ to $10 \%$ reported from major units ${ }^{12}$ and rates of $10 \%$ to $20 \%$ among insulin-dependent mothers. ${ }^{7-9}$ The incidence of complications such as congenital malformations, respiratory distress, and neonatal hypoglycaemia is also increased in this group of neonates. ${ }^{10}$ Thus it is likely that further improvements in maternal glucose concentrations can still be achieved to give a further decline in perinatal mortality and morbidity.

In non-pregnant diabetics diurnal blood glucose concentrations can be improved using subcutaneous continuous insulin infusion, which has been used in outpatients. ${ }^{11}{ }^{12}$ It seems particularly appropriate, therefore, to consider this method of insulin administration for pregnant diabetics in whom the best possible control is required over a limited time.

\section{Patients and methods}

Eight pregnant patients were studied. Table I shows their age, obstetric history, and insulin dose immediately before the start of the continuous infusion. These patients were classified using the White classification, ${ }^{13}$ which is an index of the severity of diabetes determined by its duration, age at onset, and complications. Six of the patients were established insulin-requiring diabetics before pregnancy (cases $1,2,4,6,7$, and 8 ) and two (cases 3 and 5) developed diabetes requiring treatment with insulin at the beginning of the third trimester.

During the first two trimesters the insulin-requiring patients were managed on a twice-daily insulin regimen (table $I$ ), and the insulin dose was altered according to a twice-weekly, four-point blood glucose profile (samples taken at 0700, 1100, 1500, and 2100) using an Ames Eyetone reflectance meter operated by the patient at home. 
The same regimen was used for the patients developing diabetes during pregnancy once they required insulin. Each patient was admitted at 32 weeks' gestation and the insulin dose further adjusted to achieve blood glucose concentrations of $3 \cdot 0-8 \cdot 0 \mathrm{mmol} / 1$ (54-144 $\mathrm{mg} / 100 \mathrm{ml}$ ) measured four times daily using the Ames Eyetone

TABLE I-Details of patients receiving intermittent insulin and their insulin requirements

\begin{tabular}{|c|c|c|c|c|c|c|c|}
\hline \multirow{2}{*}{$\begin{array}{l}\text { Case } \\
\text { No }\end{array}$} & \multirow{2}{*}{$\begin{array}{l}\text { Age } \\
(\mathrm{yr})\end{array}$} & \multirow{2}{*}{ Parity } & \multirow{2}{*}{$\begin{array}{l}\text { White } \\
\text { class }\end{array}$} & \multicolumn{3}{|c|}{ Dose (units) } & \multirow{2}{*}{ Total } \\
\hline & & & & am & & m & \\
\hline 1 & 28 & 1 & D & $\begin{array}{l}40 \\
32\end{array}$ & A & $\left.\begin{array}{l}28 \\
30\end{array}\right\}$ & 130 \\
\hline 2 & 28 & 0 & $\mathbf{R}$ & $\begin{array}{l}26 \\
16\end{array}$ & $\stackrel{\mathbf{A}}{\mathbf{S}}$ & $18\}$ & 72 \\
\hline 3 & 25 & 0 & $\mathbf{B}^{*}$ & $\begin{array}{l}30 \\
24\end{array}$ & $\stackrel{\vec{A}}{\mathbf{S}}$ & $24\}$ & 100 \\
\hline 4 & 34 & 0 & B & $\begin{array}{l}42 \\
28\end{array}$ & A & $16\}$ & 110 \\
\hline 5 & 20 & 0 & $\mathbf{B}^{*}$ & $\begin{array}{r}34 \\
8\end{array}$ & A & $\left.\begin{array}{r}32 \\
6\end{array}\right\}$ & 80 \\
\hline 6 & 24 & 2 & B & $\begin{array}{l}16 \\
18\end{array}$ & I & 12 & 48 \\
\hline 7 & 22 & 0 & C & & $\begin{array}{l}\text { So } \\
\text { M }\end{array}$ & $20\}$ & 90 \\
\hline 8 & 30 & 1 & $\mathbf{R}$ & $\begin{array}{l}30 \\
22\end{array}$ & $\stackrel{A}{S}$ & $\left.\begin{array}{r}18 \\
8\end{array}\right\}$ & 78 \\
\hline
\end{tabular}

Insulin preparations were as follows: $A=$ Actrapid, $S=$ Semitard, $M=$ Monotard, So = Soluble, I = Isophane.

White classification of severity of diabetes used as follows: $B$, age at onset $\geqslant 20$ $\mathrm{yr}$ and duration of diabetes $<10 \mathrm{yr} ; B^{*}$, gestational diabetes; $C$, age at onset $10-19$
$\mathrm{yr}$ or duration $10-19 \mathrm{yr} ; \mathrm{D}$, age at onset $<10 \mathrm{yr}$ or duration $\geqslant 20 \mathrm{yr} ; \mathrm{R}$, proliferative yr or duration
retinopathy.

reflectance meter. Once optimal control of diabetes was achieved a 24-hour glucose profile was obtained from samples taken hourly through the day from 0800 until midnight and at 0200, 0400, 0600, and 0700. Patients were then started on continuous infusion, and control of diabetes was re-established. A further 24-hour profile was then obtained. The infusion was maintained throughout the rest of the pregnancy and throughout delivery.

A Pye Dynamic MS16 syringe driver (weight $227 \mathrm{~g}$; size $16.5 \mathrm{~cm}$ $\times 8.0 \mathrm{~cm} \times 2.8 \mathrm{~cm}$ ) was used for insulin infusion. This was carried in a holster and allowed the patients to be freely ambulant. The syringe driver operated at 1-99 $\mathrm{mm} / \mathrm{h}$, which with disposable syringes delivered insulin at $0 \cdot 33-263$ units/h without the need to dilute the insulin. The rate of infusion was easily altered by a screw adjustment. The syringe-usually a 1- or 2-ml disposable syringe-was connected to a fine plastic catheter (Lectrocath $100 \mathrm{~cm}$; bore $1 \mathrm{~mm}$ internal, $2 \mathrm{~mm}$ external) that was connected to an Argyle Medicut gauge 20 plastic cannula sited subcutaneously in the upper arm. The cannula was held in place with tape, and the implantation site was protected by gauze and a Netalast bandage. Patients were taught to refill the syringe with insulin and to change the infusion rate over mealtimes.

A basal infusion rate was delivered to the patient, which was augmented over mealtimes. The initial basal infusion rate was 0.66 units $/ \mathrm{h}$ or 1.33 units/h depending on the insulin requirements of the patient. This was then adjusted to achieve fasting glucose concentrations of about $5.0 \mathrm{mmol} / 1(90 \mathrm{mg} / 100 \mathrm{ml})$. The augmented rates, given for one hour starting 30 minutes before the three main meals, were initially ten times higher than the basal rate. More effective control of diabetes, however, was obtained with variable mealtime augmentation, and we subsequently gave initial augmented rates of half the total insulin requirement on the twice-daily insulin regimen minus the basal dose of insulin at breakfast and one-quarter of this amount over lunch and supper. Augmented rates were then adjusted to try to limit postprandial glucose increases to $8.0 \mathrm{mmol} / 1$ $(144 \mathrm{mg} / 100 \mathrm{ml}$ ) or less. Short-acting insulins were used for infusions, the purity on continuous infusions being the same as on conventional regimens.

Protein was removed from the blood samples from the 24-hour blood glucose profiles with perchloric acid, and glucose estimations were obtained by an enzymatic spectrophotometric method. ${ }^{14}$ The blood glucose results were expressed as mean fasting concentrations and mean 24-hour concentrations; and variations in blood glucose throughout the day as standard deviations from the mean 24-hour concentrations, maximum excursions during the day, and $M$ values. The $M$ value is a quantitative index of the deviations of several blood glucose measurements during a 24-hour period from a selected standard $(4.6 \mathrm{mmol} / 1 ; 73.8 \mathrm{mg} / 100 \mathrm{ml})$ and is designed to give greater emphasis to hypoglycaemia than to hyperglycaemia. We have used the formula given by Service et $a^{15}$ (a modification of that proposed by Schlichtkrull et al $\left.^{16}\right)$ :

$$
M=\Sigma\left(10 \log _{10} B G / 4 \cdot 6\right)^{3} / n
$$

where $B G$ is the blood glucose concentration and $n$ the number of glucose estimations.

\section{Results}

The pumps proved effective for insulin administration and maintained control of diabetes for 5-55 days without mechanical failure. The batteries powered the pumps satisfactorily for two weeks, when they were routinely changed. The syringes, catheters, and cannulas did not become disconnected, and there were no complications associated with the implantation site; in particular there was no evidence of infection or atrophy of the skin. The patients were able to

TABLE II-Rates and duration of insulin infusion in patients receiving continuous infusion and their insulin requirements compared with requirements on intermittent regimen

\begin{tabular}{|c|c|c|c|c|c|c|c|}
\hline \multirow{2}{*}{$\begin{array}{c}\text { Case } \\
\text { No }\end{array}$} & \multirow{2}{*}{$\begin{array}{c}\text { Basal } \\
\text { overnight } \\
\text { rate } \\
\text { (units/h) }\end{array}$} & \multicolumn{3}{|c|}{ Augmented rate (units/h) } & \multirow{2}{*}{$\begin{array}{c}\text { Total } \\
\text { (units) }\end{array}$} & \multirow{2}{*}{$\begin{array}{c}\% \text { of } \\
\text { intermittent } \\
\text { dose }\end{array}$} & \multirow{2}{*}{$\begin{array}{c}\text { Duration } \\
\text { (days) }\end{array}$} \\
\hline & & am & Midday & pm & & & \\
\hline $\begin{array}{l}1 \\
2 \\
3 \\
4 \\
5 \\
6 \\
7 \\
8\end{array}$ & $\begin{array}{l}1.5 \\
0.66 \\
1.3 \\
1.3 \\
0.66 \\
0.66 \\
0.99 \\
0.66\end{array}$ & $\begin{array}{l}12 \\
11 \\
13 \cdot 3 \\
47 \\
30 \\
16 \\
40 \\
23\end{array}$ & $\begin{array}{l}12 \\
11 \\
13 \cdot 3 \\
20 \\
17 \\
8 \\
20 \\
15\end{array}$ & $\begin{array}{l}12 \\
11 \\
13 \cdot 3 \\
20 \\
17 \\
8 \\
20 \\
15\end{array}$ & $\begin{array}{r}73 \\
48 \\
96 \\
112 \\
78 \\
46 \\
97 \\
67\end{array}$ & $\begin{array}{r}56 \\
67 \\
96 \\
102 \\
98 \\
96 \\
108 \\
91\end{array}$ & $\begin{array}{r}5 \\
17 \\
17 \\
7 \\
20 \\
15 \\
55 \\
21\end{array}$ \\
\hline
\end{tabular}

TABLE III-Control of blood glucose in patients receiving intermittent insulin regimen and continuous infusion

\begin{tabular}{|c|c|c|c|c|}
\hline \multirow{2}{*}{ Case } & \multicolumn{2}{|c|}{$\begin{array}{c}\text { Mean } \\
\text { concentration }(\mathrm{mmol} / \mathrm{l}) \\
\end{array}$} & \multirow{2}{*}{$\underset{\substack{\text { Maximum } \\
(\mathrm{mmol} / \mathrm{l})}}{\text { Maxion }}$} & \multirow{2}{*}{$\begin{array}{c}M \\
\text { value }\end{array}$} \\
\hline & $24 \mathrm{~h} \pm \mathrm{SD}$ & Fasting & & \\
\hline $\begin{array}{l}1 \\
2 \\
3 \\
4 \\
5 \\
6 \\
7 \\
8\end{array}$ & $\begin{array}{l}\quad \text { In } \\
4 \cdot 3 \pm 2 \cdot 3 \\
8 \cdot 3 \pm 4 \cdot 8 \\
7 \cdot 5 \pm 2 \cdot 1 \\
5 \cdot 5 \pm 2 \cdot 1 \\
5 \cdot 6 \pm 2 \cdot 1 \\
5 \cdot 2 \pm 1 \cdot 2 \\
6 \cdot 8 \pm 2 \cdot 2 \\
6 \cdot 1 \pm 3 \cdot 3\end{array}$ & $\begin{array}{c}\text { rmittent } \\
3.5 \\
3.4 \\
4.5 \\
5 \cdot 2 \\
7 \cdot 2 \\
4.0 \\
6 \cdot 8 \\
8.0\end{array}$ & $\begin{array}{r}9.5 \\
16.3 \\
6.1 \\
7.3 \\
6.7 \\
4.1 \\
6.3 \\
10.8\end{array}$ & $\begin{array}{r}14 \\
47 \\
13 \\
8 \\
6 \\
2 \\
12 \\
24\end{array}$ \\
\hline $\begin{array}{l}\text { Group } \\
\text { mean }\end{array}$ & $6 \cdot 2 \pm 2 \cdot 5$ & $5 \cdot 3$ & $8 \cdot 4$ & 16 \\
\hline $\begin{array}{l}1 \\
2 \\
3 \\
4 \\
5 \\
6 \\
7 \\
8\end{array}$ & $\begin{array}{l}\text { Contin } \\
8 \cdot 0 \pm 2 \cdot 2 \\
8 \cdot 9 \pm 3.6 \\
6 \cdot 4 \pm 2 \cdot 1 \\
4.9 \pm 1 \cdot 4 \\
3.9 \pm 1 \cdot 2 \\
5 \cdot 6 \pm 2 \cdot 0 \\
4.9 \pm 2.0 \\
4.3 \pm 1.5\end{array}$ & $\begin{array}{c}\text { cous infusic } \\
7.4 \\
8.0 \\
9 \cdot 6 \\
6.0 \\
4.9 \\
3.2 \\
4.7 \\
6.0\end{array}$ & $\begin{array}{r}8.8 \\
14.3 \\
6.8 \\
5.0 \\
4.6 \\
6.3 \\
7.7 \\
5.5\end{array}$ & $\begin{array}{r}21 \\
42 \\
10 \\
4 \\
5 \\
5 \\
11 \\
16\end{array}$ \\
\hline$\underset{\text { mean }}{\text { Group }}$ & $5 \cdot 9 \pm 2 \cdot 0$ & $6 \cdot 2$ & $7 \cdot 4$ & 14 \\
\hline
\end{tabular}

Conversion: SI to traditional units-Blood glucose: $1 \mathrm{mmol} / \mathrm{l} \approx 18 \mathrm{mg} / 100 \mathrm{ml}$.

alter the rate of infusion before and after meals and recharge the syringe with insulin without difficulty. The recharging procedure was straightforward, although care was needed to prevent air bubbles accumulating in the catheter. The patients were mobile and could wash, bathe, and sleep without hindrance. All the patients became interested in the technique and were keen to refill the syringe and alter the infusion rates themselves. Five patients were able to go home at weekends, where they maintained their infusions satisfactorily.

Table II shows the infusion rates and doses of insulin. Basal infusion rates varied from 0.66 to $1.5 \mathrm{units} / \mathrm{h}$. Although this was a narrow range, small changes in basal rate within this range had a 
considerable effect on fasting blood glucose concentrations. The augmented rates varied from 8 to 47 units/h. There was considerable variation in requirements between patients and in the same patient between meals. We found that better control of diabetes could be obtained with variable mealtime augmentation of the infusion rate, with more insulin always being required at breakfast than at other mealtimes. In one patient (case 5), who required insulin injections four times daily before continuous infusion, control was readily obtained with this pattern of variable mealtime augmentation on continuous infusion.

Table III shows the control of blood glucose concentration on intermittent insulin regimens and on continuous infusion. The mean 24-hour blood glucose concentrations were similar on both regimens $(6.2 \mathrm{mmol} / 1(111.6 \mathrm{mg} / 100 \mathrm{ml})$ on intermittent regimens; and 5.9 $\mathrm{mmol} / 1(106.2 \mathrm{mg} / 100 \mathrm{ml})$ on continuous infusion). Fasting glucose concentrations tended to be higher on continuous infusion $(6 \cdot 2$ $\mathrm{mmol} / 1 ; 111.6 \mathrm{mg} / 100 \mathrm{ml})$ compared with intermittent regimens $(5.3 \mathrm{mmol} / 1 ; 95.4 \mathrm{mg} / 100 \mathrm{ml})$, but the lower concentrations on intermittent regimens were associated with episodes of nocturnal hypoglycaemia in some patients. There was, however, a trend towards a reduction in the variation of blood glucose concentrations during the day on continuous infusion as shown by the lower standard deviation $(2.5 v 2.0 \mathrm{mmol} / 1 ; 45 v 36 \mathrm{mg} / 100 \mathrm{ml})$ maximal excursion $(8.4 v$ $7.4 \mathrm{mmol} / 1 ; 151.2 v 133.2 \mathrm{mg} / 100 \mathrm{ml}$ ), and $M$ value (16 $v 14)$.

\section{Discussion}

Since the increased perinatal mortality and morbidity associated with diabetes during pregnancy can be decreased by better maternal diabetic control, ${ }^{5}{ }^{\circ}$ it is necessary to determine ways of improving this control. The development of portable open-loop systems for long-term insulin administration has considerably improved the control of blood glucose concentrations. ${ }^{17}$ Some of these systems infuse insulin intravenously, ${ }^{18}$ but subcutaneous continuous insulin infusion with its comparatively safer route of administration presents attractive possibilities for use in pregnant diabetics. This system would be expected to give a more physiological supply of insulin than once-daily or twice-daily injections, since carbohydrate loads would be more effectively offset by individually adjusted mealtime augmentations of the infusion rates, and the postabsorptive states would be covered by a low but steady supply of insulin rather than the varying concentrations available on twice-daily injections. These benefits would be particularly useful in the management of pregnant diabetics, in whom the best possible control of blood glucose concentration is required for a limited time.

We have shown the infusion system used in this study to be practical and reliable. Neither the batteries nor the pump failed, and there were no problems with the connections between the pump and the implantation site. Furthermore, control of diabetes was sustained for long periods in individual patients, some of whom were also able to use the technique while at home during the weekend.

Our findings show that satisfactory mean 24-hour and fasting glucose concentrations can be obtained by paying constant attention to conventional insulin regimens. Good mean 24-hour concentrations and fasting concentrations may, however, be achieved despite considerable variations in blood glucose concentration throughout the day. It is occasionally found that satisfactory fasting glucose concentrations are not obtained without producing nocturnal hypoglycaemia and that limitation of rises in postprandial glucose concentration produces hypoglycaemia before the subsequent meal. In this study continuous infusion achieved mean 24-hour and fasting glucose concentrations similar to those produced by intermittent insulin treatment. When variations in blood glucose concentrations were considered, however, continuous infusion was shown to reduce standard deviations, maximum excursions, and $M$ values. These results, based on initial experience with continuous infusion compared with extensive experience with conventional regimens, show a trend towards decreased diurnal variations in blood glucose.
With further development and use of this method of administration of insulin appreciable improvements in the control of diabetes may become apparent that could be beneficial in the management of pregnant diabetics during the third trimester.

We thank Dr R V Hague and Dr J D Ward for referring their patients; Professor I D Cooke, Mr W Porter, and Mr T Smith for their co-operation in the obstetric management of these patients; and Professor C N Hales from the department of clinical biochemistry, University of Cambridge, for his help in performing the blood glucose estimations. JMP is supported by a research grant from Novo Laboratories.

Requests for reprints should be addressed to Dr D R Cullen.

\section{References}

1 Pedersen J, Molsted-Pedersen L, Andersen B. Assessors of fetal perinatal mortality in diabetic pregnancy. Diabetes $1974 ; 23: 302-5$.

${ }^{2}$ Essex N, Pyke D, Watkins PJ, Brudenell JM, Gamsu HR. Diabetic pregnancy. $\mathrm{Br}$ Med $\mathcal{F} 1973$;iv:89-93.

${ }^{3}$ Harley JMG, Montgomery DAD. Management of pregnancy complicated by diabetes. $\mathrm{Br}$ Med $\mathcal{F} 1965 ; \mathrm{i}: 14-8$.

4 Gellis SS, Hsia DY. The infant of the diabetic mother. Am 7 Dis Child $1959 ; 97: 1-41$.

5 Pedersen J, Brandstrup E. Foetal mortality in pregnant diabetics. Lancet $1956 ; \mathrm{i}: 607-10$.

- Oakley W. The treatment of pregnancy in diabetes mellitus. In: Leibel BS, Wrenshall GA, eds. On the nature and treatment of diabetes. Amsterdam: Excerpta Medica Foundation, 1965:673-8.

7 Karlsson K, Kjellmer I. The outcome of diabetic pregnancies in relation to the mother's blood sugar level. Am $\mathcal{F}$ Obstet Gynecol 1972;112: 213-20.

${ }^{8}$ Haworth JC, Dilling LA. The effect of abnormal glucose tolerance in pregnancy on infant mortality rate and morbidity. Am $\mathcal{F}$ Obstet Gynecol 1975;122:555-60.

- Malins J. Fetal anomalies related to carbohydrate metabolism: the epidemiological approach. In: Sutherland HW, Stowers JM, eds. Carbohydrate metabolism in pregnancy and the newborn. Berlin: SpringerVerlag, 1979:229-46.

${ }^{10}$ Pedersen J. The neo-natal period. In: The pregnant diabetic and her newborn. Copenhagen: Munksgaard, 1977:178-97.

11 Pickup JC, Keen H, Parsons JA, Alberti KGMM, Rowe AS. Continuous subcutaneous insulin infusion: improved blood glucose and intermediary metabolite control in diabetics. Lancet $1979 ; \mathrm{i}: 1255-7$.

12 Tamborlane WV, Sherwin RS, Genel M, Felig P. Restoration of normal lipid and amino acid metabolism in diabetic patients treated with a portable insulin-infusion pump. Lancet 1979 ;i:1258-61.

13 White P. Pregnancy and diabetes: medical aspects. Med Clin North Am $1965 ; 49: 1015-24$

14 Bergmeyer HU, Bernt E, Schmidt F, Stork H. D-Glucose. Determination with hexokinase and glucose-6-phosphate dehydrogenase. In: Bergmeyer HU, ed. Methods of enzymatic analysis. 2nd ed. New York: Academic Press, 1974:1196-1201.

15 Service FJ, Molnar GD, Rosevear JW, Ackermann E, Gatewood LC, Taylor WF. Mean amplitude of glycaemic excursions, a measure of diabetic instability. Diabetes 1970:19:644-55.

${ }^{16}$ Schlichtkrull J, Munck $O$, Jersild $M$. The $M$ value, an index of blood sugar control in diabetics. Acta Med Scand 1965;177:95-102.

17 Santiago JV, Clemens AH, Clarke WL, Kipnis DM. Closed loop and open loop devices for blood glucose control in normal and diabetic subjects. Diabetes $1979 ; 28: 71-81$.

18 Irsigler K, Kritz H. Long term continuous intravenous insulin therapy with a portable insulin dosage regulating apparatus. Diabetes 1979; 28:196-203.

(Accepted 5 February 1980)

ONE HUNDRED YEARS AGO We read in the Times of a novel and startling addition to telegraphic possibilities, viz., "seeing by telegraph." By means of a lens, an image of the object is thrown upon a receiving plate. This is built up of a series of thermopile elements grooved anteriorly to an even surface, and connected by their posterior ends with a series of wires which transmit the electric currents generated by the reception of the image to a similar series of elements in a second plate at a distance. In this second plate, the electric currents create changes exactly corresponding to those produced by the image on the receiving plate. The close analogy between this apparatus and the rods and cones of the retina and the fibres of the optic nerve is obvious. (British Medical fournal, 1880.) 